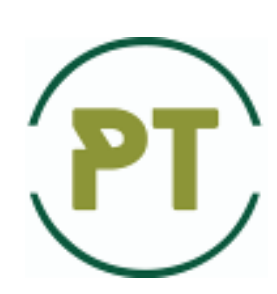

\title{
Improvement of functional properties of gas-thermal coatings by electro- contact treatment
}

\author{
I. Smirnov ${ }^{1}$, A. Lopata ${ }^{1}$ T. Smirnova ${ }^{2}$ L. Lopata ${ }^{3^{*}}$ \\ ${ }^{I}$ National Technical University of Ukraine "Igor Sikorsky Kyiv Polytechnic Institute," Kyiv, Ukraine \\ ${ }^{3}$ Central Ukrainian National Technical University National technical, Kropyvnytskyi, Ukraine \\ ${ }^{3}$ G. S. Pisarenko. Institute for Problems of Strength of the National Academy of Sciences of Ukraine, Kyiv, Ukraine \\ *E-mail: beryuza@ukr.net
}

\begin{abstract}
Among the current technological and material study areas of science and technology, the problem of surface engineering is one of the most significant. Combination of coating deposition with the following modification of the surface and its treatment is especially up-to-date.

The creation of coatings ensuring the operability of machines and equipment in extreme conditions of operation has been and remains relevant. There are various techniques for deposition of protective coatings.
\end{abstract}

Key words: electric arc coating, wear resistance, adhesion strength, electric arc spraying

\section{The state of the problem and the purpose of the research}

Among the current technological and material study areas of science and technology, the problem of surface engineering is one of the most significant. Providing the surfaces of machine parts, working bodies, tools, and other structures with the necessary physical, chemical, and performance properties is most successfully implemented when using approaches and technological methods for surface engineering. Via coating and modifying surface layers, it is possible to significantly improve the performance and reliability of parts and structures, to provide them with new, not achievable by other methods, functional properties. Promising are methods for surface engineering which combine coating with surface modification or processing.

Without the use of modern high-technology for hardening protective coatings, Ukraine's economy will not come out of the crisis of an acute shortage of metal, spare parts, electricity, and fuel. The use of coatings prolongs the service life of parts by increasing their wear and corrosion resistance, restoring performance, and also by replacing expensive materials with cheaper ones with coatings. Moreover, the use of coatings can markedly reduce the cost of alloyed steels and alloys. In this case, it is possible to create products with a unique combination of properties that are unattainable when using traditional structural materials. The coating material is usually chosen on the basis of the substrate material and operation conditions.

There are various methods for deposition of protective coatings. The variety of types of coating is due to the fact that none of them can claim to be universal. The accumulated experience shows that there are no universal methods that are effective for hardening a variety of parts, since each method has its own scope, advantages and disadvantages.

Coatings are multifunctional. They can help regulate thermal conductivity, provide the surface with corrosion resistance, wear resistance, specific performance properties (electrical, optical, anti-friction, etc.). Coatings are a promising way to protect against exposure to high heat fluxes and corrosive media. The creation of coatings ensuring the operability of machines and equipment under extreme operation conditions (exposure to high temperature, wear, aggressive media) has been and remains an important and urgent task.

The use of coatings is associated with the implementation of a fundamentally new approach to the creation of structural materials: the strength and carrying capacity of a part are provided by the base material, whereas the resistances to corrosion wear, and other harmful factors - by a coating. Most methods for coating deposition can be considered as alternative. The same coating material can be deposited in different ways. The complex 
of mechanical properties and operation characteristics of the coated part depends on the method for obtaining the coating.

Promising are methods of gas-thermal spraying (GTS), whose current level of technology allows the solution of problems of high-temperature corrosion and wear in the power industry, aircraft and automobile construction, turbine construction, petrochemistry, metallurgy and other fields of industry. Methods of gas-thermal spraying (GTS) are promising (Table 1).

Table 1

Methods of gas-thermal spraying

\begin{tabular}{|l|c|c|c|c|}
\hline \multirow{2}{*}{ Parameter } & \multicolumn{4}{|c|}{ Method for spraying } \\
\cline { 2 - 5 } & electric arc & gas-plasma & plasma & detonation \\
\hline Efficiency, $\mathrm{kg} / \mathrm{h}$ & $3 \ldots 31$ & $1 \ldots 10$ & $0,5 \ldots 8,0$ & $0.1 \ldots 6.0$ \\
\hline $\begin{array}{l}\text { Coefficient of material } \\
\text { consumption }\end{array}$ & $0.8 \ldots 0.9$ & $0.8 \ldots 0.95$ & $0.4 \ldots 0.9$ & $0.3 \ldots 0.6$ \\
\hline $\begin{array}{l}\text { Strength of } \\
\text { adhesion, } \mathrm{MPa}\end{array}$ & to 40 & to 50 & to 60 & to 200 \\
\hline $\begin{array}{l}\text { Temperature of part } \\
\text { heating, }{ }^{\circ} \mathrm{C}\end{array}$ & $100 \ldots 150$ & $100 \ldots 150$ & $50 \ldots 200{ }^{\circ} \mathrm{C}$ & $100 \ldots 15$ \\
\hline
\end{tabular}

The investigations of K.A. Yushchenko, Yu.S. Borisov, Yu.A. Kharlamov, M.I. Chernovol, V.S. Ivashko, and M.A. Belotserkovskyi have shown that in order to create wear-resistant coatings, it is advisable to use cheaper and easier to implement methods for gas-thermal spraying, in particular, gas-flame (GFS) and electric arc (EDS) spraying (table 1).

However, with the implementation of these methods, there was revealed insufficient hardness, relatively low density and adhesion strength of coatings, which required the use of additional techniques for their treatment by impregnation, thermal, chemical-thermal treatment and mechanical-thermal processing. (Fig. 1).

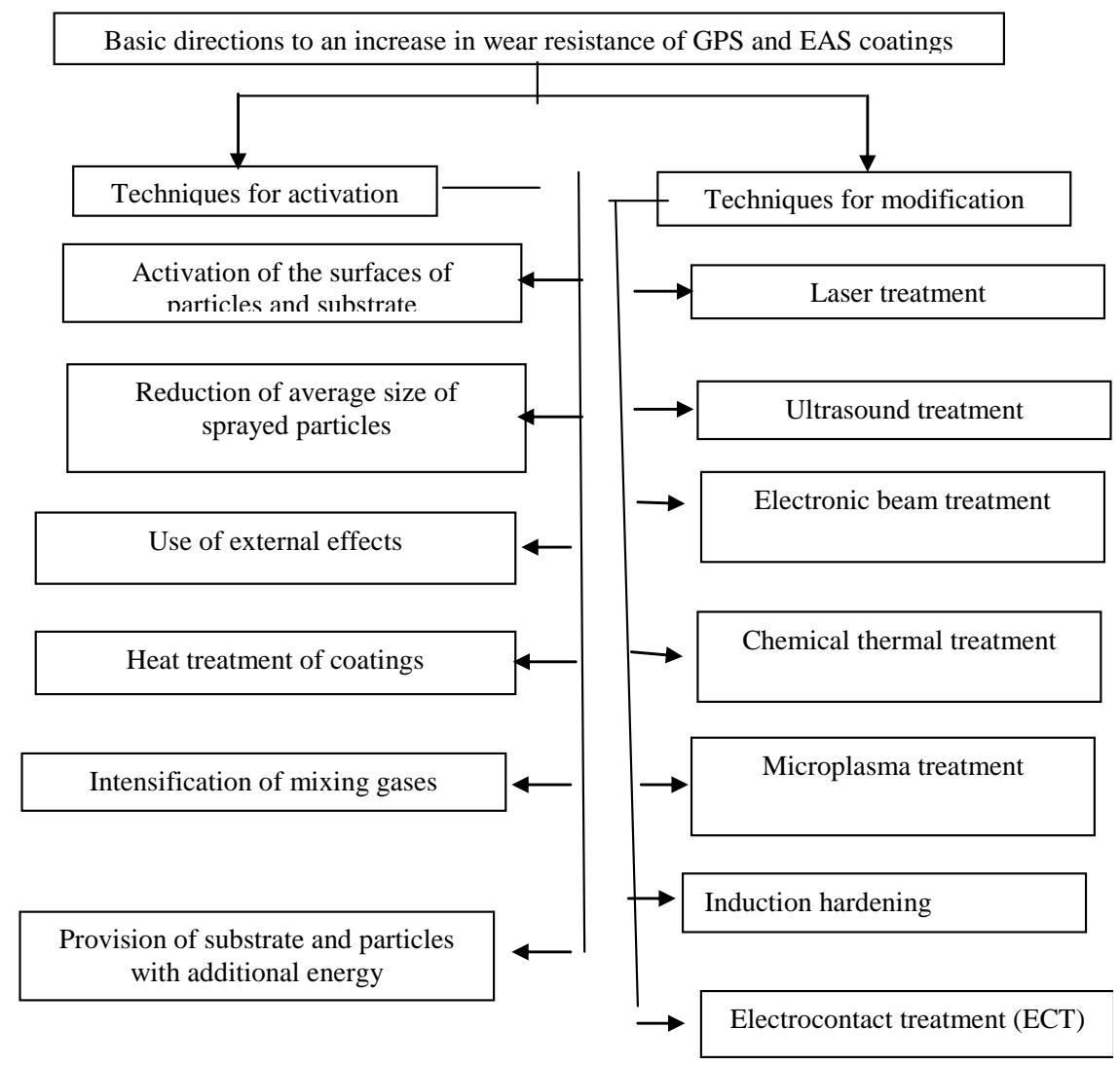

Fig. 1. Basic directions to an increase

in wear resistance of GPS and EAS coatings

Treatment of coatings should ensure their impermeability to corrosive environments, increase the strength of coating -to -substrate adhesion, hardness, and wear resistance. 
The transition of the economy to the path of intensive development involves the use of coating processing methods that are implemented using autonomous or joint effects of temperature, mechanical, and chemical factors. The application of methods with the minimum necessary heating and small values of allowances is of great importance. In this regard, the mechanical-thermal processing is of considerable interest (Fig. 1).

One of the most effective mechanical methods is an electrocontact treatment (ECT). Its advantages include: minimum heat input and finishing allowances. One of the most effective methods of mechanical-thermal processing is electrocontact treatment (ECT) (Fig. 2, 3, Table 2). Its advantages include minimum heat input and finishing allowances.

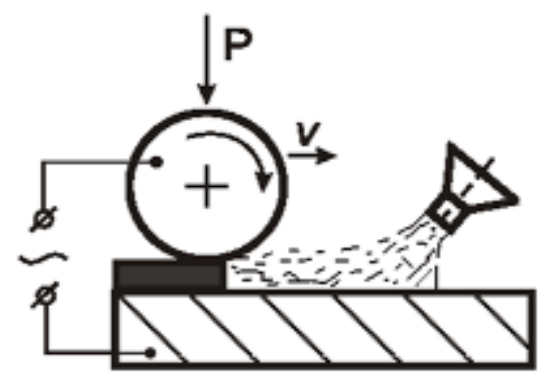

Fig. 2. Scheme of gas-thermal coating

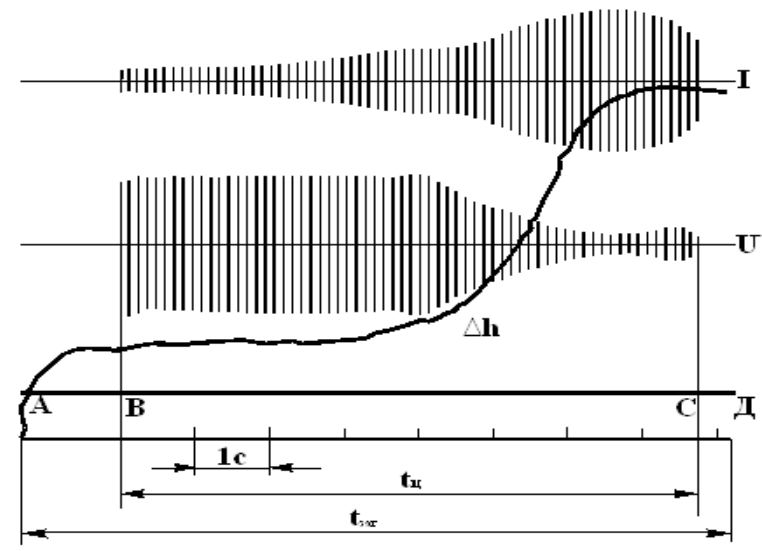

Fig. 3. Stages of electric pulse treatment

Table 2

Parameters of electrocontact treatment

\begin{tabular}{|l|c|c|c|}
\hline \multicolumn{1}{|c|}{ Process parameters } & Notation & Unit & Value \\
\hline Current strength & $I$ & $\mathrm{kA}$ & $15-30$ \\
\hline Pulse duration & $t_{i m p}$ & $\mathrm{~s}$ & $0.02 \ldots 0.06$ \\
\hline Pause duration & $t_{p}$ & $\mathrm{~s}$ & $0.02 \ldots 1.0$ \\
\hline Pressure on electrode & $P$ & $\mathrm{MPa}$ & $10 \ldots 60$ \\
\hline Secondary voltage & $U_{2}$ & $\mathrm{~V}$ & $3 \ldots 6$ \\
\hline $\begin{array}{l}\text { Temperature of baking } \\
\text { the surface }\end{array}$ & $T$ & $\mathrm{~K}$ & $(0.9 \ldots 0.98) \mathrm{T}_{\mathrm{m}}$ \\
\hline $\begin{array}{l}\text { Initial electric resistivity } \\
\text { of powder layer }\end{array}$ & $\rho_{0}$ & $\Omega \cdot \mathrm{m}$ & $(15 \ldots 6) \cdot 10^{-5}$ \\
\hline Rate of heating & $d T / d t$ & $\mathrm{~K} / \mathrm{s}$ & $10^{3} \ldots 10^{4}$ \\
\hline
\end{tabular}

Advantages of electrocontact processing:

- minimum heat-affected zone on the part $(0.1 \ldots 0.3 \mathrm{~mm})$ due to small duration of the heating pulse;

- the absence of a liquid phase in the hardening zone significantly expands the technological capabilities of the process: it allows one to increase the thickness of the wear-resistant layer by $3-6$ times (coating thickness up to $3 \mathrm{~mm}$ and more), increases the electrode durability, reduces the cost of the coating material, and contributes to a more uniform distribution of physic mechanical properties.

- provides almost poreless coatings with adhesion strength of 150-220 MPa, while maintaining the initial properties of the material.

- high performance $(0.01 \ldots 0.015 \mathrm{~m})$ and low energy consumption $0.25 \ldots 0.60 \mathrm{kWh} / \mathrm{m}$

\section{The purpose of the work and tasks}

The purpose of the work was to improve the functional properties of gas-thermal coatings by electrocontact treatment.

In accordance with the work purpose, the research program included (Fig. 4) the following tasks:

- to analyze GTS methods (table 1) as ones of the methods for controlling the properties of surfaces and to substantiate the choice of EAS for reinforcing and renovating parts and constructions;

- to consider the main directions of improving the quality of sprayed coatings (Fig. 1);

- to justify the choice of ECT to improve the properties of GTS coatings (Fig. 2); 
- to study the effects of the EAS apparatus design, the scheme of formation of metal-air flow, spraying distance, and other factors on the EAS process, such as dispersion, forming drops and fixing the sprayed particles on the part surface, and the coating properties;

- to show the possibility of controlling the EAS factors (parameters of the gas-thermal flow, temperature of propane-air mixture jet, sprayed particles, jet velocity, spraying distance) in order to improve the properties of coatings;

- to determine the microhardness of EAS coatings from 40CeKh13 steel in the initial state and after ECT;

- to study the effect of ECT on the physico-mechanical properties of sprayed coatings (porosity, adhesion strength, wear resistance);

- to optimize the modes of ECT of sprayed coatings;

- to develop practical recommendations for enhancing the functional properties of EDS coatings by ECT using the example of restoring and hardening the rotor shaft of a compressor unit.

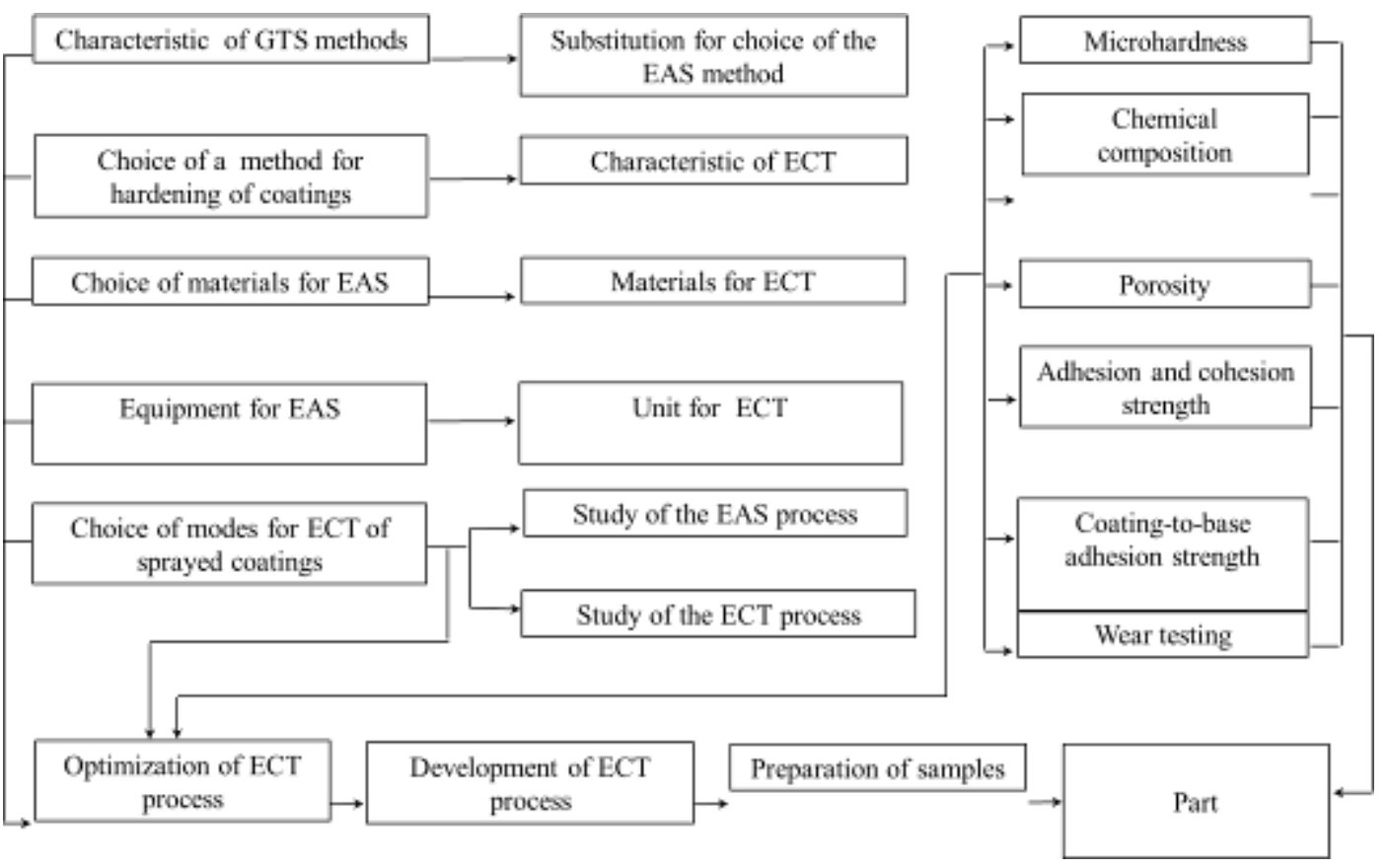

Fig. 4. General scheme of the experimental studies

Table 3

Parameters of unit for electrocontact treatment

\begin{tabular}{|l|c|}
\hline \multicolumn{1}{|c|}{ Parameter } & Value \\
\hline Primary voltage, $\mathrm{V}$ & 380 \\
Secondary voltage, $\mathrm{V}$ & $3.3 \ldots 6.6$ \\
Primary current, A & $100 \ldots 450$ \\
Current for baking the surface, $\mathrm{kA}$ & $8 \ldots 30$ \\
Efficiency, $\mathrm{cm}^{2} / \mathrm{min}$ & to 120 \\
Maximum load on electrode, $\mathrm{KN}$ & $1 \ldots 3$ \\
Width of the upper electrode, $\mathrm{mm}$ & $8 \ldots 16$ \\
Pulse duration, $\mathrm{s}$ & $0.02 \ldots 0,4$ \\
Spindle speed, rev/min & $0.6 \ldots 1.5$ \\
Thickness of coating, mm & $0.15 \ldots 3$ \\
\hline
\end{tabular}

Friction and wear tests were carried out on an upgraded machine of the 2070 SMT-1type. The machine had been designed for testing metals, alloys and rigid engineering plastics with data recording in PC.

The machine is composed of a test facility, a control panel and a data collection system for registering in PC. The principle of the machine functioning consists in abrasion of a pair of samples pressed one to one with a given force. During the test, the rotational speed, friction torque, compression force, amount of wear, and the number of operating cycles are recorded. It is possible to record temperature and tests in various environments. 


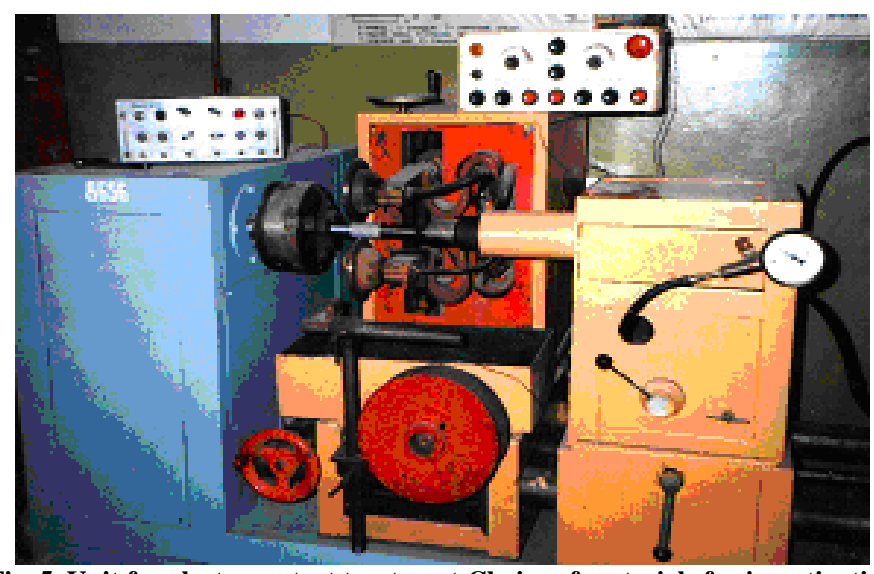

Fig. 5. Unit for electrocontact treatment Choice of materials for investigation

The automated system for collecting analytical data makes it possible to simultaneously register up to 10 parameters in numerical values and graphical display with saving the results obtained in Microsoft Word and Microsoft Excel.

\section{Composition of the charge components of cored wires PP FMI-1, FMI-2}

\begin{tabular}{|c|l|c|c|c|c|c|c|c|}
\hline \multirow{2}{*}{ Charge } & \multirow{2}{*}{ Components of the charge } & \multirow{2}{*}{ GOST, TU } & \multicolumn{5}{|c|}{ Chemical composition, \% } \\
\cline { 4 - 9 } & & & C & C & B & Al & Ti & Fe \\
\hline \multirow{2}{*}{ FBKh+Al + Ligature FBKh } & TU 95.14.10-93 & 50 & & 20 & 7 & 3 & 20 \\
\cline { 2 - 8 } & Al (PA-40) & & & & & 99.3 & & \\
\hline \multirow{2}{*}{$\mathrm{FKh}+\mathrm{Al}$} & Ferrochrome FKh-800 & GOST 9849-74 & 73 & 8,3 & & & & \\
\cline { 2 - 9 } & Al(PA-40) & & & & & 99.3 & & \\
\hline
\end{tabular}

\section{Practical significance of the research results}

The technological process of restoring the rotor shafts of a compressor has been developed by using electric arc spraying of coatings followed by their electrocontact treatment (Fig. 6, 7).

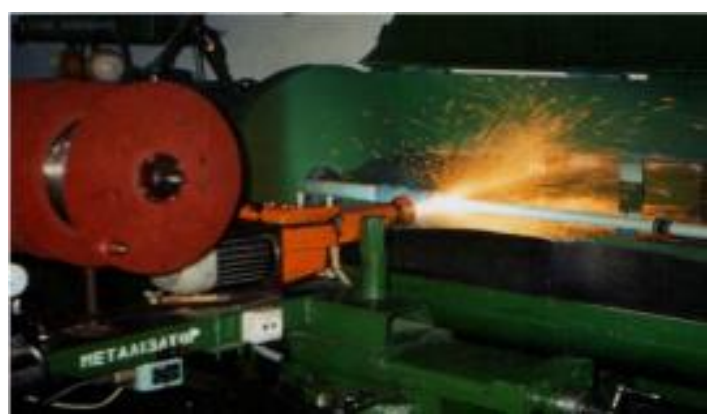

$\mathbf{a}$

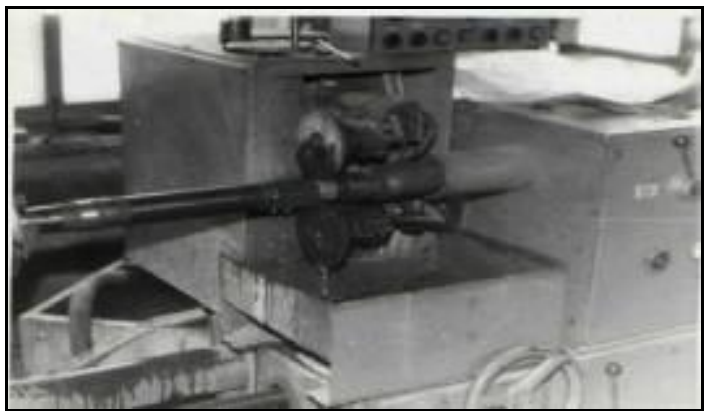

b

Fig. 6. Electric arc spraying of coatings (a) and their electrocontact treatment (b)

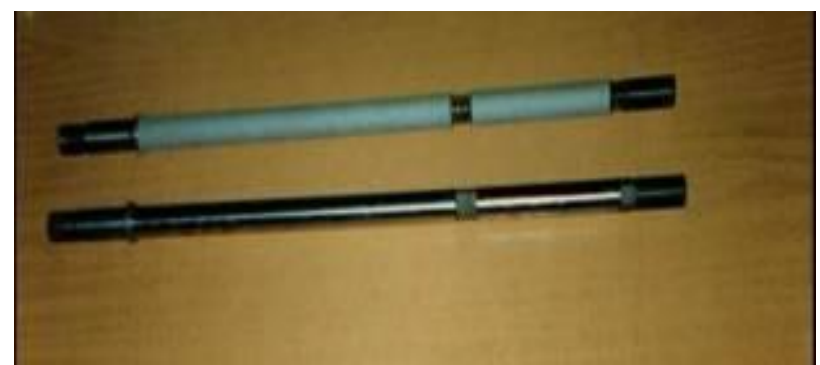

Fig. 7. Compressor piston rod

(cylinder 1KU 2GM = 4) with coatings 


\section{Conclusions}

1. For the first time, it has been shown that ECT of sprayed coatings reduces their porosity down to 2.08 $\ldots 3.03 \%$, increases microhardness to $7.4 \ldots 8.5 \mathrm{GPa}$ and wear resistance by $2 \ldots 4$ times at optimal ECT parameters (current strength $I=6.0 \mathrm{kA}$, pressure $\mathrm{P}=30 \mathrm{MPa}$, pulse and pause duration $0.04 \mathrm{~s}$.).

2. For the first time, it has been shown that a smooth decrease in microhardness through the thickness of sprayed coatings after their ECT ensures adhesion strength of coatings of $180-200 \mathrm{MPa}$ and minimizes the probability of their detachment.

3. For the first time, it has been established that the high coating-to-part adhesion strength after ECT is associated with the phenomenon of anomalous mass transfer, in particular with the accelerated migration of atoms under the electroplastic effect due to the formation of a significant diffusion interlayer. A proper combination of pressure and current pulses makes it possible to realize the electroplastic effect, which, reducing the power parameters of the process, can attribute it to the energy-saving technology.

4. Electrocontact treatment of sprayed coatings using residual heat allows obtaining "dimensional coatings" with the required accuracy and surface cleanliness with minimal finishing machining or without it.

5. Optimization of the technological parameters for ECT of sprayed coatings relative to a set of mechanical properties allows to control the ECT and so provide obtaining EAS coatings of the required quality.

\section{References}

1. Iliuschenko A.F. Formation of gas-thermal coatings: theory and practice / Iliuschenko A.F. Okovity V.A., Kundas S.P., Formanek B. - Minsk, 2002.

2. Theory and practice of gas-thermal spraying / Vitiaz P.A., Ivashko V.S., Manoilo E.D. and others. Minsk: Science and Technology, 1993. - 295 p.

3. Gas-thermal spraying / L.Kh. Baldaev et al. - Market DS, 2007. 344 p.

4. Kharlamov Yu.A. Thermal spraying of coatings and ecological compatibility of production, operation and repair of machines / Yu.A. Kharlamov // Heavy engineering- №2. 2000 - P. 3-10.

5. Boronenkov V.N., Korobov Yu.S. Fundamentals of arc metallization. Physicochemical regulairities. USU; 5/ Yekaterinburg: Univ. Publ. house 2012, 267 p.

6. Vilage B., Rupprecht K., Pokhmurskaya A. Features of gas-thermal spraying with flux-cored wires. Automatic welding, No.10. 2011. P. 26-30.

7. Pokhmursky V.I. Protective and restorative electric metallization of coatings from cored wires // V.I. Pokhmursky, M.M. Student, V.S. Pikh // New processes and equipment for gas-thermal and vacuum coating: Coll. of papers "Electric welding"- Kyiv, 1990. P. 66 - 69.

8. Student M.M. Development of old and new electrometallic coatings to cover powder darts: Thesis. Lviv, 1998 - 18 p.

9. Vitiaz P.A., Azizov R.O., Belotserkovsky M.A. Hardening of gas-thermal coatings. - Minsk: Bestprint, 2004. - 192 p.

10. Pokhmurska G.V., Dovgunik V.M., Student M.M. Wear resistance of laser-modified electric arc coatings from cored wire FMI-2 // FKhMM № 4. - 2003. P. 61-64.

11. Korobov Yu.S. Efficiency of using activated arc coating metallization / Yu.S. Korobov // Welding Production, No. 2. 2005. P. 47-50, 62, 64.

12. Priadko A.S., Korobov, Yu.S., Lukanin V.L. Activated arc metallization: the characteristics of the equipment and its application // Films and Coatings 98: Proc. $5^{\text {th }}$ Inter. conf. Saint-Pb. 1998. P. $249-251$.

13. Belotserkovsky M.A. Technological features and areas of using hypersonic metallization / M.A. Belotserkovsky, A.S. Pryadko, A.E. Cherepko // Innovations in mechanical engineering: Coll. of papers. Minsk, OIM NAS Belarus. 2008. -P. 479 - 484.

14. Belotserkovsky M.A., Kukareko V.A., Azizov P.O. Obtaining wear-resistant coatings by activated gas-thermal spraying followed by modifying // Probl. material science, № 2, 2004. P. 77-87.

15. Belotserkovsky M.A. Structural anomalies in steel gas-thermal coatings and the possibility of their use / M.A. Belotserkovsky // Strengthening Technologies and Coatings, 10, 2008. P. 39-44.

16.Vitiaz P.A, Belotserkovsky M.A., Kukareko V.A., et al. Structure and properties of coatings from steel 40Kh1 produced using various methods for gas-thermal spraying // Physical mezomechanika.-, V.5, No. 1. 2002 P. 15-22.

17. Priadko A.S., Dudan A.V., Brusilo Yu.V., et al. Choice of equipment for hardening and restoring automotive transport parts by arc spraying. Polotsk, Bull. of Polotsk State University. 3, 2014, P. 121-126.

18. Brusilo Yu.V. Choice of equipment for hardening and restoring parts of piston engines by arc spraying. J. "Aerospace Engineering and Technology" Kharkiv. No. 4 (71), 2010. P. 38-42.

19. Podcherniaeva I.A. Laser reflow of gas thermal coatings based on cortinite // Technol. and body. - № 2. 1992. P. 42-43.

20. Prokhorenkova N.V. The structure and properties of coatings based on Ni deposited by a plasma jet and subjected to electron irradiation // International school "Physics and Chemistry of Nanomaterials", Tomsk: TSU, 2005. -P.118-120. 
21. Improving the quality of gas-thermal coatings from wire materials by means of chemical heat treatment / P.A. Vitiaz, R.O. Azizov, M.A. Belotserkovsky, V.A. Kukareko // Friction and wear. - Vol. 24, No. 6. 2003. - P. 666-672.

22.Belotserkovsky M.A. Hardening by chemical heat treatment of coatings obtained by fast spraying steel wires / M.A. Belotserkovsky, V.M. Konstantinov, G.A. Tkachenko // Surface Engineering, Welding: Proc. Int. Symp., Minsk, 2009. P. 178-184.

23. Sokolov Yu.V., Sadova M.A., Popok, D.A. Heat treatment of sprayed coatings / Vest. Belarus tech. inst. № 3, 2004. - P. 40-41.

24. Liashenko B.A., Belotserkovsky M.A., Lopata V.N., et al. Thermal spraying and ion nitriding as a promising combination. Proc. $14^{\text {th }}$ Inter. Conf., June 2014, Svaliava - Kyiv: ATM of Ukraine, P.79-80.

25. Lopata L.A. Improvement of sprayed coatings / L.A. Lopata, N.A. Medvedeva, T.M. Tunik, S.G. Salii / J. "World of Engineering and Technologies", 8 (54), 2005. P. 54-56. 
Смирнов И.В., Лопата А.В., Смирнова Т.В., Лопата Л.А. Повышение свойств газотермических покрытий электроконтактной обработкой.

В работе на основании проведенного обзора литературы, патентно-информационных и экспериментальных исследований установлено, что электроконтактная обработка (ЭКО) напыленных покрытий повышает их когезионную и адгезионную прочность до 180 ... 200 МПа, плотность до 98 ... 99 \% износостойкость в $2,5 \ldots 5$ раз при таких параметрах обработки, как: силе тока $I=6,0 \ldots 8,0$ кА, времени импульсов $t_{u, ~} /$ пауз $t_{\text {п тока }}=0.04$ с., давлении $P=29 \ldots 30$ МПа.

Повышение свойств напыленных покрытий ЭКО определяется эффективностью действия двух составляющих: термической и механической. Термический фактор обусловливает интенсивный нагрев материала покрытия до температуры плавления основной его составляющей и создает благоприятные условия для протекания диффузионных процессов. Механический фактор определяет формирование упрочненных структур.

Практическое использование электроконтактной обработки для повышения функциональных свойств напыленных покрытий было применено при восстановлении и упрочнении вала ротора нагнетателя компрессорной установки

Ключевые слова: электроконтактная обработки, электродуговое напыление, покрытия, прочность сцепления, пористость, сила тока, давление, время импульсов и пауз тока 